\title{
As Despesas de Caráter Secreto ou Reservadas
}

\section{JURANDYR COELHO}

A existência das chamadas despesas de caráter secreto ou reservadas, malgrado as procedentes objeções que se lhes pussam apresentar, é um fato concreto e que, nos quadros orçamentário do país, se estigmatiza de maneira inapelável. Nêsse sentido examinem-se os orçamentos nacionais nesses últimos anos e, via de regra, verificar-se-á que são várias as unidades administrativas contempladas com quantitativos destinados a atender aquêle mister: Minis. tério da Fazenda, Ministério da Guerra, Ministério da Justiça, Ministério da Marinha, etc.

Em verdade, se a finalidade dêsse dispêndio deve ser, tôda ela, dirigida no sentido de atender ao objetivo que diz respeito à estabilidade e à manutenção da crdem jurídica do país, é evidente que a homogeneidade de destinação da despesa que, no caso, se deve fazer sentir, se perde em meio à verdadeira dispersão dos recursos distribuídos a repartições estatais que objetivam finalidades senão opostas, mas bem diferentes quanto ao seu campo de ação. Ao que se possa inferir, não parece razcável que o equilíbrio social e a ordem pública devam refletir-se no orçamento, como que assentes em bases de sustentação das mais diferentes contexturas, como está a indicar essa disseminação heterogênea das verbas. Não é compreensível, em face disso, a ausência de um denominador comum para que exista, na crigem daqueles gastos e na sua destinação, um critério único de apreciação. Se efetivado êste último ponto de vista, a que órgão deveria caber tal incumbência?

Considere-se que as Secretarias de Estado, abrangendo em seu âmbito inúmeros órgãos, cujos orçamentos consignam autorizaçãc para efetuar a movimentação de créditos reservados, têm competência específica para gerir os negócios que thes cabem promovendo, para êsse fim, as medidas que julgarem acertadas. Ora, reafirmando pensamento anterior, a estabilidade das instituições jurídicas não se pode prender a critérios de ordem diversos, conforme seja encarado o aspecto da atividade privativa do órgão.

A estabilidade jurídica do país - que justifica a disposição e a utilização de recursos orçamentários, sob o caráter de secreto - exige uma apreciação genérica, uma vista de clhos em conjunto sôbre tôda a máquina governamental. A manutenção dêsse ponto de vista está, portanto, em que não se pode considerar a questão sob o ponto de vista unilateral. Não é apenas um órgão que se beneficia da paz pública. É tôda a administração governamental que se sente atingida se algum dos seus componentes fôr atingidc. Dessa forma não se explica a disseminação das dotações orçamentárias, tidas como reser- 
vadas porque, além de enfraquecer a autoridade de tais despesas, permite critérios arbitrários na sua aplicação.

Assim a institucionalização de um órgão centralizador, para a execução orçamentária dessas verbas, é medida que se impõe e se impõe não como a criação ou a configuração de uma entidade suscetível de criar novos encargos - como tão comumente acontece - mas, apenas, como uma entidade de assessoramento capaz de unificar, de maneira rigorosa, a razão de ser e a destinação daquelas despesas que fugem à norma comum de aplicação orçamentária.

A êsse respeito a legislação ordinária trata especificamente do assunto, principalmente no que diz respeito à incidência da competência do Tribunal de Contas, nesse particular. Remontando, aliás, à época não muito longínqua, já o Código de Contabilidade Pública e c Regulamento Geral de Contabilidade Pública dispunham nos seus artigos 92 e 904, respectivamente:

"Art. 92. As despesas secretas com diligências policiais, feitas pela Tesouraria da Polícia da Capital Federal, por conta dos adiantamentos para tal fim concedidos, ou quaisquer outros de mesma natureza que a lei do orçamentc entenda criar, serăo anualmente verificadas, logo após o encerramento do exercício, por uma Comissão especial, nomeada pelo Presidente do Tribunal de Contas, a qual fará uma sindicância completa nas mesmas Tesourarias para verificar a comprovação das mesmas despesas e, em relatóric secreto, exporá ao Tribunal o resultado do seu exame.

Art. 904. As despesas secretas com diligências policiais, feitas pela Tesouraria da Polícia da Capital Federal, por conta dos adiantamentos para tal fim concedidos, ou quaisquer outrcs da mesma natureza que a lei de orçamento entender criar, serão anualmente verificadas, após o encerramento do exereício, por uma Comissão especial nomeada pelo Presidente do Tribunal de Contas, a qual fará uma sindicância completa na mesma Tescuraria para verificar a comprovação dos mesmos e, em relatório secreto, entregue diretamente ao Presidente daquele Tribunal, exporá ao mesmo resultado do seu exame."

Nesse dispositivos se estrutura todo um regime de fiscalização. Determina-se o registrc prévio. A época de prestação de contas (fim do exercício). A incidência das despesas (diligências policiais ou outras semelhantes desde que devidamente autorizadas em lei). O sistema de fiscalização (Comissão Especial nomeada pelo Presidente do Tribunal de Contas). A forma de fiscalização (sindicância completa na Tesouraria e relatório secreto dirigido ao Presidente do Tribunal).

Anualmente a lei n. $^{\circ} 830$ de 23 de setembro de 1949 que reorganizou o Tribunal de Contas, também trata do assunto nos seus artigos 43 e 44 . Assim dispõe o artigo 43:

"As despesas de caráter reservado e confidencial não serão publicadas e terão registro em face de comprovação aprcpriada, desde que o crédito próprio as comporte." 
A enunciação de princípios que aí se contém - a par de permitir a infringência do princípio da publicidade orçamentária - de onde não serem jamais publicadas as despesas que sob aquêle epiteto tiverem sidc ou vierem a ser feitas - conduz a um entendimento nem sempre preciso. Na afirmação de que tais créditos terão "registro em face de comprovação apropriada, desde que o crédito próprio as comporte" observa-se que com reservas deve ser entendida a expressão - em face de comprovação apropriada - eis que, se movimentados sob a forma de adiantamentos e, porque em tal caso, as despesas ainda não foram efetuadas - apenas pode ser exigido como único elemento para o registro de tais dotações - a suficiência de crédito. Esta exigência, aliás, em época bem anterict, esta característica já se fazia sentir em face do artigo 171 do decreto n. ${ }^{\circ} 2.409$, de 23 de dezembro de 1896 ("a mais completa negação de qualquer fiscalização" - Ministro TAVARES DE LYRA), como segue:

"As despesas de caráter reservado e confidencial serão registradas desde que o crédito da respectiva consignação as compcrtar. A nota da confidencial ou reservada posta no aviso ou no mandado de pagamento pelo ordenador é suficiente para que o Tribunal sem maiores indagações proceda nos têrmos da primeira alínea dêste artigo."

Por outra forma, fazendo menção a - registro de crédito e comprovação de despesa - referido dispositivo confunde a função do Tribunal, quando registra créditos, em que age ccmo fiscal da administração financeira, com aquela que lhe compete como Tribunal de Justiça, no julgar da legalidade da aplicação dos dinheiros públicos. Essa dicotomia de atribuições confiadas ao Tribunal de Contas não pode ser exercida conjuntamente na mesma ocasião e em que pese o critério daqueles que impugnam êsse desdobramento de competências é forçoso ainda que as decisões que nessas hipóteses surgem são bem diferentes, quanto ao fundo e quanto à forma.

No tocante à forma, o sistema e a especificidade do julgamento dos gastos de natureza secreta, conclui o artigo 44 da lei já citada:

"As despesas a que se refere o artigo 43 serão anualmente verificadas, logo após o encerramento do exercício, por uma Comissão especial, nomeada pelo Presidente do Tribunal de Contas.

$\S 1^{\circ}$ Tais despesas serão comprcvadas pelas ordens de pagamento e demais documentos que demonstrem a sua efetivação.

$\S 2 .^{\circ}$ Os processos de tomada de contas de tais despesas serão feitos em caráter reservado e julgados pelo Tribunal em sessão secreta".

O caráter genérico da disposição legislativa, em face de uma categcria especial de despesa, só pode tornar a aplicação da lei falha, e essa afirmativa diz tudo, quando existe a impossibilidade de exemplificar as conseqüencias de ordem prática que promanam daquelas normas. E, mesmo assim, tais despesas serão julgadas pelo Tribunal em sessão secreta. Dessa forma, a lei submete à apreciação do Tribunal a comprovação de despesas que são secretas. 
Secretas, porque assim o determina a ordem jurídica do país. Secretas, de onde apenas ser necessário a suficiência de crédito para o competente registro. Secretas e, por isso mesmo, não publicadas. Secretas, de onde serem comprovadas apenas mediante ordens de pagamento cu qualquer documento que demonstre a sua aplicação. E, na afirmação taxativa de que não se pode impor o silêncio sôbre a situação jurídica do responsável pela aplicação, é também justo que se deixe ao sabor da interpretação a resposta para as indagações que podem ser feitas: Pode o Tribunal de Contas infirmar a natureza da despesa? Secreta ou não? Pode ser exigido um documento sabidamente secreto ou essa exigência, se feita, tornará ainda mais inoperante o regime de fiscalização? Pode, por ausência de elementos, impor-se o silêncio em tôrno ao mérito das contas apresentadas? Pode ser promovida a cobrança executiva de despesas secretas, consideradas irregulares, sem prejuizo do seu caráter de - secretas?

Tudo isso está a indicar que é necessário o abandono de fórmulas arcaicas por um fluxo renovador na apreciação de tal problema - delicado e difícil de ser tratado - no sentido de que se torne possível a conciliação da natureza dessas despesas, com a homogeneidade de sua destinação e maior rigidez na sua fiscalização, sem prejuízo dos interêsses que se ligam de perto à segurança nacional. 